\title{
Occlusal trauma can not be compared to orthodontic movement or Occlusal trauma in orthodontic practice and V-shaped recession
}

\author{
Alberto Consolaro ${ }^{1}$
}

The mechanisms of tissue changes induced by occlusal trauma are in no way comparable to orthodontic movement. In both events the primary cause is of a physical nature, but the forces delivered to dental tissues exhibit completely different characteristics in terms of intensity, duration, direction, distribution, frequency and form of uptake by periodontal tissues. Consequently, the tissue effects induced by occlusal trauma are different from orthodontic movement. It can be argued that occlusal trauma generates a pathological tissue injury in an attempt to adapt to new excessive functional demands. Orthodontic movement, in turn,performs physiological periodontal bone remodeling to change the position of the teeth in a well-planned manner, eventually restoring normalcy.

Keywords: Occlusal trauma. Occlusion. Gingival recession. Gingiva abfraction. Orthodontics.

Os mecanismos das alterações teciduais induzidas pelo trauma oclusal não são minimamente comparáveis aos do movimento ortodôntico. Embora ambos os eventos tenham uma causa primária de natureza física, essas forças aplicadas sobre os tecidos dentários têm características completamente distintas na intensidade, tempo, direção, distribuição, frequência e forma de absorção pelos tecidos periodontais. Por consequência, os efeitos teciduais induzidos no trauma oclusal são diferentes do movimento ortodôntico. Pode-se afirmar que o trauma oclusal gera uma lesão tecidual de natureza patológica, na tentativa de se adaptar a novas demandas funcionais excessivas. Por sua vez, o movimento ortodôntico utiliza-se da remodelação óssea periodontal fisiológica para mudar o dente de posição, de forma planejada e com posterior restabelecimento da normalidade.

Palavras-chave: Trauma oclusal. Oclusão. Recessão gengival. Gengiva. Abfração. Ortodontia.

\section{OCCLUSAL TRAUMA AS A CLINICAL CONDI- TION OR CLINICAL ENTITY}

The condition or clinical entity known as occlusal trauma is synonymous with occlusion trauma, traumatic occlusion, traumatogenic occlusion, periodontal traumatism, occlusal overload, among others.

The name of a given clinical condition seeks to identify the type of injury or set of changes it causes in the affected tissues. Terminological precision and standardization fa-

${ }^{1}$ Full Professor, FOB-USP. Full Professor, graduate program, FORP-USP.

Alberto Consolaro:E-mail: consolaro@uol.com.br

" The author reports no commercial, proprietary or financial interest in the products or companies described in this article. cilitate the search for information in databases as well as communication between scholars and researchers.

The term injury means: Any structural change, irrespective of its nature, which can be transient or permanent. The injury induced in periodontal tissue characterized as the clinical condition called occlusal trauma may be caused by traumatic occlusion or overload of occlusal forces in single or multiple teeth simultaneously, depending on the clinical situation.

How to cite this article: Consolaro A. Occlusal trauma can not be compared to orthodontic movement. Dental Press J Orthod. Dental Press J Orthod. 2012 NovDec;17(6):5-12.

Submitted: October 11, 2012 - Revised and accepted: October 17, 2012 
The injury induced in the clinical condition or entity known as occlusal trauma was classically defined by Stillman ${ }^{10}$ in 1917, as stemming from a situation in which the act of occluding the jaws damages the tissues that support the teeth. ${ }^{8,9}$ In 1978, the World Health Organization (WHO) described the injury known as occlusal trauma as damage induced to the periodontium by pressure against the teeth produced directly or indirectly by antagonist teeth. ${ }^{8,9}$ On the other hand, the American Association of Periodontology describes occlusal trauma as injury to the dental supporting apparatus resulting from excessive occlusal forces. ${ }^{8,9}$

The three definitions of occlusal trauma given above share the concept that damage is necessarily produced by overload induced by the teeth in occlusion and by the antagonist teeth.

\section{OCCLUSAL TRAUMA SHOULD NOT BE LIKENED TO ORTHODONTIC MOVEMENT}

Human teeth are capable of enduring heavy occlusal loads that produce intrusive movements in the alveoli, mainly during mastication. Injuries to this apparatus are caused by very strong, persistent, or repetitive forces. Even in this situation, the periodontal ligament - with an average thickness of $0.25 \mathrm{~mm}$, or $250 \mu \mathrm{m}$ - will not allow the teeth to touch the apical alveolar cortical surface. This underscores a structural organization that comprises a perfect physiological apparatus, which enables insertion of the tooth in its socket.

The periodontal ligament is a delicate membrane overlying the root surface and connecting the latter to the alveolar bone. Fifty percent of its structure is composed of vessels. Although efficient for intrusive forces, it will not handle lateral forces, so that when one is intent on moving teeth orthodontically: ${ }^{1}$

» Forces are often lighter.

» Applied slowly,and gradually dissipating.

» Teeth either incline or perform bodily move-

ment. Therefore, forces must be incomparably

lighter than in the case of occlusal trauma.

After each period of appliance activation, the periodontal tissues return to normal, allowing new forces to be applied with the same characteristics: Light, in one go,with forces that dissipate. ${ }^{\text {This dif- }}$ fers in almost everything if one tries to compare orthodontic movement to occlusal trauma, especially in regard to induced cellular and tissue reactions and their consequences.

\section{OCCLUSAL TRAUMA AND ORTHODONTIC PRACTICE}

One of the major objectives of clinical orthodontic practice is to correct occlusion disorders, especially those involved in the relationships between the jaws and dental arches. Professional orthodontic training, however, is usually not thorough enough or suitable for detecting more detailed occlusal interferences. In Brazilian Dentistry, within the scope of clinical specialties, there are professionals who specialize in the examination, diagnosis and correction of occlusion and temporomandibular disorders.

Orthodontic movement induces some occlusal interferences, but these are temporary and generally do not last long enough to significantly injure the periodontal support structures. The changes inherent in occlusal trauma require prolonged action by the damaging forces, affecting one and the same site.

At the end of orthodontic treatment, it is not a widespread conduct to perform a thorough occlusal analysis on discharging the patient, thereby allowing a natural "accommodation" to settle over the subsequent months. ${ }^{3}$ However, in many cases the patient complains and exhibits changes that are typical of occlusal trauma in specific teeth.

Ideally, this analysis should be performed on all finished orthodontic cases, and professionals should be well trained to diagnose interferences and correct them. But this is not observed in current clinical practice. ${ }^{3}$ Where necessary, one should resort to an expert on occlusion for this analysis and correction of possible changes in the patient's occlusion. ${ }^{3}$

Occlusal trauma in one or more teeth may be associated with parafunctional responses such as clenching and bruxism. The causes of occlusal trauma in orthodontic practice may be related to premature contacts arising from the position of teeth, inappropriate occlusal morphology between antagonist teeth, overload on lateral incisors when these teeth are laterally involved in canine guidances, and postoperative periods following orthognathic surgeries.

In a recent article, ${ }^{12}$ the author of this study described some of the phenomena involved in the emer- 
gence of $\mathrm{V}$-shaped gingival recession resulting from occlusal trauma. Part of the information provided in the article will be repeated here for purposes of consistency in understanding the effects of periodontal occlusal trauma, especially in isolated teeth.

\section{V-SHAPED GINGIVAL RECESSION IN OCCLUSAL TRAUMA: BACTERIAL PLAQUE DON'T NEED TO BE PRESENT!}

Primarily, occlusal trauma can cause gingival recession, especially V-shaped recession. Some scholars, notably in Scandinavia, ${ }^{8,11}$ refuse in principle to accept this finding, and believe that in order for gingival recession to occur it should always be associated with an accumulation of bacterial plaque. This stance has sparked much controversy and heated debate.

One of the reasons why the Scandinavians claim that bacterial plaque must be present if gingival recession is to develop in occlusal trauma can be explained by the focus of their studies and rationale: They compare occlusal trauma to orthodontic movement, and even call it "orthodontic trauma."1

Occlusal trauma promotes cell and tissue changes, which are entirely distinguishable from the phenomena induced by orthodontic movement. ${ }^{1}$ Whereas occlusal trauma is characterized by repeated and intense forces over time, orthodontic forces are much lighter than occlusal trauma, occurring slowly and progressively. Besides, orthodontic forces start subsiding within 3 to 6 days, gradually dissipating within 7 to 10 days in humans. ${ }^{1}$

\section{GINGIVAL RECESSIONS: CONCEPT}

Gingival recessions can be generalized, compromising several or almost all teeth. Localized recessions can be caused by several factors depending on how they emerge, and are classified as atrophic changes in periodontal tissues.

U-shaped or circular recessions are closely associated with the presence of bacterial plaque and chronic inflammatory periodontal disease, frenular attachments, poor brushing technique, and other less common causes.

V-shaped or angled gingival recessions have a small fissure at their most apical end. This type of recession is directly correlated with occlusal trauma, ${ }^{9}$ and is commonly associated with abfraction. ${ }^{2,4,7}$ In the ma- jority of early cases, eliminating occlusal trauma leads to a reduction or regression of this V-shaped recession. ${ }^{9}$ In many cases one cannot determine a direct relationship with bacterial plaque accumulation.

\section{OCCLUSAL TRAUMA IN MINERALIZED STRUCTURES AND ABFRACTION}

In areas of occlusal interference, occlusal trauma determines the presence of wear facets, caused by friction $^{5,6}$ over time. Likewise, excessive pressure or eccentricity of forces cause three-dimensional deformations in the mineralized tooth structure, which can be called temporary and repetitive deflections.

Deflection is the act or effect of deflecting, a verb that indicates a movement that deviates from a given line in order to follow another direction - this line can be referred to as the long axis of the tooth. A deflection in the tooth, on deviating from the long axis, can create traction on one side and compression of mineralized structures on the other side.

Cementum and dentin are deformable, but enamel is not. Dentine is comprised on average of $60 \%$ inorganic component, and $40 \%$ organic component, predominantly proteins and water. On the other hand, $50 \%$ of the cementum structure consists of organic matter, and $50 \%$ inorganic. Together, dentin and cementum form a structure with relative flexibility, and not prone to structural changes.

Enamel, with its $96 \%$ of mineral component, has a minimum, negligible deflection capacity. On the compression side - during deflection of the tooth as a whole, by occlusal trauma, for example - the enamel resists its effect, but on the traction side, enamel cannot resist, and presents with early fractures and/or cracks in its delicate cervical portion. This process, if repetitive, can lead to fragmentation and loss of enamel structure, which is medically known as abfraction (Figs 2 and 3). Abfraction is very common, especially in youths and in premolars. ${ }^{2,4,7}$

The cracks cannot be seen in the cervical enamel of premolars experiencing this condition. The patient, however, may complain of intense sensitivity to thermal variations in these "healthy" teeth when eating. If the tooth displays wear facets and Vshaped recession, one may suspect the presence of abfraction, even if only initial, albeit not observable, which would explain this enhanced sensitivity. 
OCCLUSAL TRAUMA IN THE INTERDENTAL SURFACE OF THE PERIODONTAL LIGAMENT AND ALVEOLAR BONE CREST

Compression of the periodontal ligament in primary occlusal trauma is accompanied by a reduction in the diameter of the vessels and disorganization of fibers and cells. This situation induces cellular stress, with release and increased accumulation of mediators in the periodontal ligament, especially those mediators that can locally determine a higher or lower rate of bone remodeling.

The local mediators of bone remodeling have a biphasic effect: When accumulated at very high levels, they stimulate bone resorption, while at slightly increased levels they induce new bone formation.

The forces delivered to the tooth determine a lever with intra-alveolar rotation and fulcrum located between the middle and apical thirds of the tooth root. In occlusal trauma, forces tend to be well distributed in the periodontal ligament and overload promotes slightly increased levels of bone remodeling mediators.

This tissue dynamic in occlusal trauma allows one to observe radiographically the thickening of the lamina dura (Figs 2 to 5), by increasing cortical bone deposition in the alveolar bone, and enhancing the

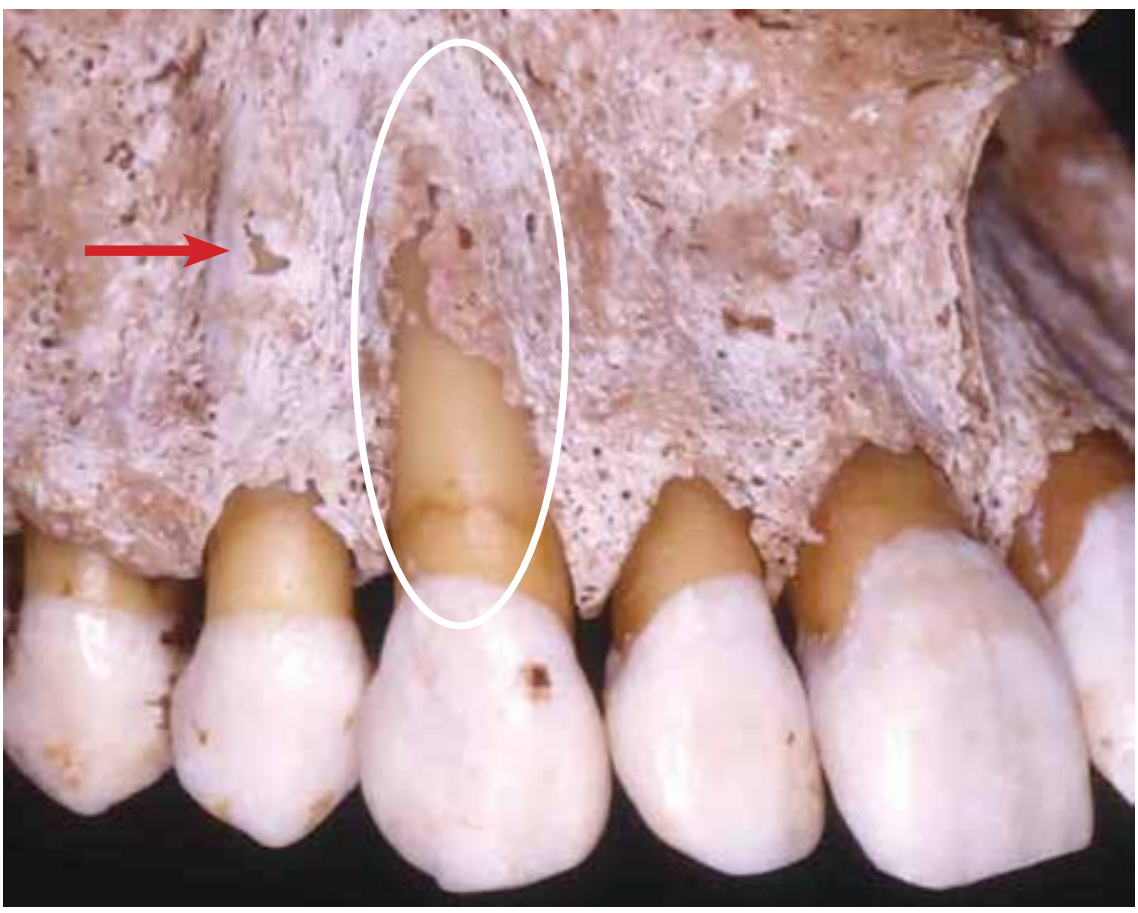

Figure 1 - Buccal cortical bone of maxillary canine with dehiscence, also showing a small fenestration in the first premolar (arrow).Note the sensitivity of buccal alveolar cortical bone thickness. resilience of this structure and stretching the collagen fibers. That is, the periodontal structures will conform better to absorb the increased occlusal forces.

In primary occlusal trauma, collagen fibers must be renewed faster, and the longer and the better organized its bundles, the greater their absorption capacity, and the more effectively excessively repetitive forces are suppressed. Radiographically, one can notice an irregular widening of the periodontal space since the ligament is constantly undergoing structural reorganization (Figs 2 to 5).

In occlusal trauma, forces are excessive and eccentric, but the periodontal tissues adapt by thickening the alveolar cortical bone, increasing adjacent trabecular density and irregularly widening the periodontal space. This happens throughout the length and width of the tooth root and surrounding tissues.

In the cervical region of periodontal tissues - given the lever effect produced by the tooth - if occlusal trauma grows too intense and persistent it can cause stretching/traction and/or excessive compression of the periodontal ligament. In the cervical region, the accumulation of mediators may rise to the point of stimulating predominantly the activity of bone resorption. The plane parallel to the tooth surface of the lamina dura in this region may undergo some angulation, implying V-shaped bone loss (Figs 3 to 5).

The imaging of this Vshaped bone loss shows some vertical bone loss with no periodontal pocket on probing thoroughly and appropriately. By simply removing the primary cause, i.e., the occlusal trauma, one can restore the original bone level.

Occlusal trauma can thus show its first radiographic signs, i.e., V-shaped vertical cervical bone loss, thickening of the lamina dura, irregular widening of periodontal space, and increases in density or apical bone sclerosis, or in the bone crest (Figs 2 and 5).These signs reflect an attempt by the 
periodontal tissues to adapt to a new functional demand. Much later, there may be areas of inflammatory root resorption.

\section{EFFECTS OF OCCLUSAL TRAUMA ON THE BUCCAL FREE SURFACE OF THE PERIODONTAL LIGAMENT AND} ALVEOLAR CORTICAL BONE

The same cellular and tissue phenomena that occlusal trauma can induce in the periodontal surface of the ligament facing the alveolar bone crest when subjected to the same type of load and consequent deflection, can also be induced in the free buccal surface. However, the structure of the buccal cortical bone tends to be very thin, and any slight resorption in its periodontal surface can lead to decreased cervical height and V-shaped bone dehiscence on the buccal surface of the affected root (Fig 2).

Buccal bone dehiscences are local and specific, and they grow in size through a gradual and slow process. Detection in imaging can be particularly challenging, although some sophisticated tomographic equipment claim to deliver reliable results. Fenestrations may also arise (Fig 1).

Upon the emergence of buccal bone dehiscence, the periosteum initially remains in place for a clinically indefinite period. With no bones to coat it, protect it and nourish it with their vessels, the periosteum tends to settle on the margins of the bone dehiscence, and follow these margins while leaving the root surface exposed to gingival and periodontal connective tissue (Fig 12).

\section{V-SHAPED GINGIVAL RECESSION IN OCCLUSAL TRAUMA -MECHANISM}

Buccal bone dehiscences temporarily enable the linking of two very similar structures, which are ultimately fused and reorganized into one single structure over time. The plate or buccal alveolar cortical bone becomes - sometimes very delicately - interposed between the periosteum and the periodontal ligament.

The periosteum is composed of two distinct layers and continuous fibrous connective tissue. The very fibrous outer layer has few cells and naturally joins the richly cellularized and vascularized inner layer. This inner layer directly interfaces with the periosteum and is intersected by fibers which become strongly attached to the mineralized part of the cortical bone.

In the human skeleton, it is only in the insertion of the tendons and in the alveolar cortical bones that the bone surface is not covered by the periosteum. The periodontal ligament sometimes plays the part of periosteum on the alveolar surface. It can be said that the periodontal ligament provides another manner in which to organize the periosteum.

When the cortical bone is lost due to resorption and dehiscence on the buccal surface of the tooth experiencing primary occlusal trauma, the two structures become temporarily juxtaposed, but over time, they should reorganize themselves. With no bone in the region and with the periosteum and periodontal ligament now joined together, the two structures no longer play an active role functionally. The fibrous connective tissue resulting from this condition gradually starts functioning by elongating the connective tissue and attached gingiva, positioned far away from the cervical bone due to the dehiscence.

Bone loss causes the periosteum and ligament to bind together by contiguity or proximity, thereby producing an elongated connective attachment and modified biological distance between the junctional epithelium and cervical bone. If the occlusal trauma persists, there is no way to keep the periodontal fibers functionally attached to the cementum given the lack of anchorage due to the absence of bone.

Gradually, the periodontal fibers that lack anchorage and the neighboring periosteum without bone reorganize themselves as normal gingival connective tissue. The connective attachment is joined by hyperplasia and epithelial migration, with the development of a long junctional epithelium, which can resist and persist keeping the gingival level at a normal height for a certain period of time under the occlusal trauma.

In continuation, the occlusal trauma may ultimately result in the bone dehiscence being accompanied by the gingival tissue in the form of a V-shaped gingival recession. Recessions are classified among periodontal diseases as atrophic changes. Without function, increased gingival connective tissue - due to bone loss - tends to remodel itself by volume and organization, similarly to what is found in gums of 
normal teeth, but this results in exposure of the dental root involved in the process.

The decrease in tissue volume in gingival recession is due to the periodontal tissue adapting to a new function, since there is no bone in the area of dehiscence. The reduction in volume occurs by means of constant and normal tissue remodeling. This remodeling accomplishes the goal of normalizing the tissue relationship and thus restoring the normal proportions between bone, gingival submucosal connective tissue and mucosal, sulcus and junctional epithelia.

While the gingival level is maintained, despite vertical bone loss - provided there is no periodontal pocket - removal of primary occlusal trauma can reverse the process even in the presence of considerable bone loss. In cases where the root has already been exposed in the mouth, restoring the gingival level usually requires surgical procedures with or without gingival and bone tissue grafting.

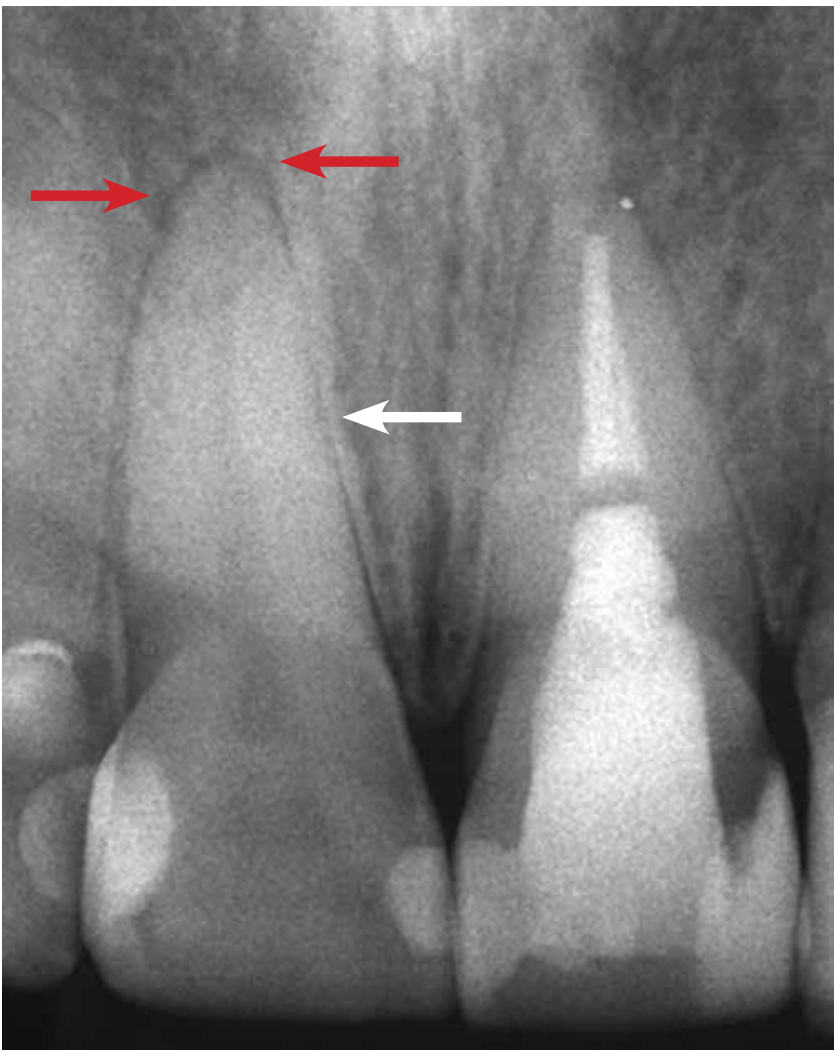

Figure 2 - Occlusal trauma with thickening of the lamina dura (white arrow) and widening of the periodontal space with increased diffuse periodontal bone density (red arrows).

\section{CRITERIA FOR EARLY DIAGNOSIS OF OCCLUSAL TRAUMA}

Primary occlusal trauma can manifest itself clinically in a subtle and inchoate manner, as a triad:2,4,7

»Wear facets in areas of interference.

»Abfraction, especially in premolars.

» Mild V-shaped recession.

Even before the appearance of V-shaped recession when only facets and abfraction are present, these signs should indicate to the clinician the need for a thorough periodontal examination and search for radiographic signs in periapical films, such as:

» Increased thickness of the lamina dura.

» Irregular widening of the periodontal space.

"V-shaped cervical vertical bone loss.

» Bone sclerosis in the periapical region and/or interdental bone crest.

» Inflammatory root resorption, more common in the advanced stages of occlusal trauma

Friction-related wear facets ${ }^{5,6}$ and abfraction

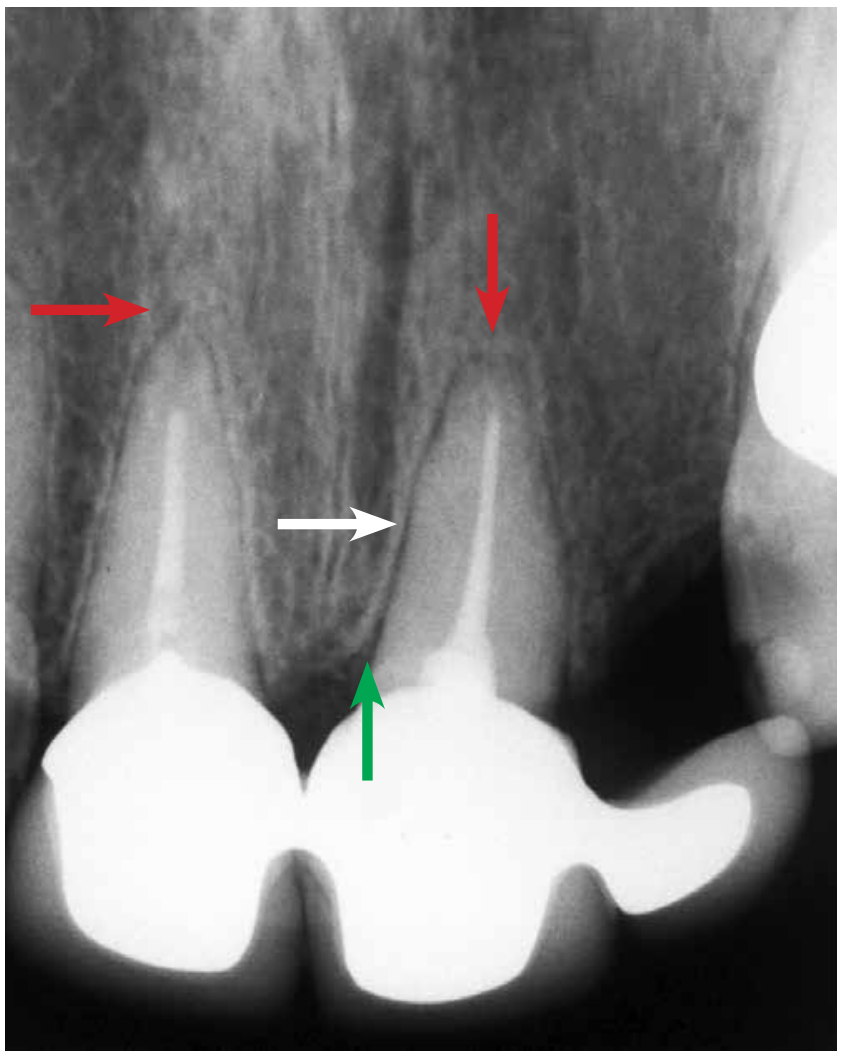

Figure 3 - Occlusal trauma with thickening of the lamina dura (white arrow) and widening of the periodontal space with increased diffuse periodontal bone density (red arrows), and vertical bone loss (green arrow). 
should be corrected, but not without first correcting the occlusal interference, even when gingival recession is already present.

Early diagnosis considerably improves the prognosis of V-shaped gingival recession, and elimination of occlusal trauma may in many clinical cases lead to spontaneous regression.

\section{GRAFTS IN V-SHAPED GINGIVAL RECESSION ASSOCIATED WITH OCCLUSAL TRAUMA}

When gingival recession appears very severe it could mean that the root surface was exposed too long in the mouth under the action of bacterial plaque, thereby irreversibly contaminating the root structure with lipopolysaccharides (LPS).

These surfaces contaminated by LPS, even after relentless scraping and/or treatment with a wide range of acidic and antimicrobial substances, will not allow cementoblastic cells to recolonize them to the point of forming new cementum layers. In other words, it will be impossible to reattach periodontal fibers to these surfaces, even after gingival grafts.

In some case reports, the most that can be achieved

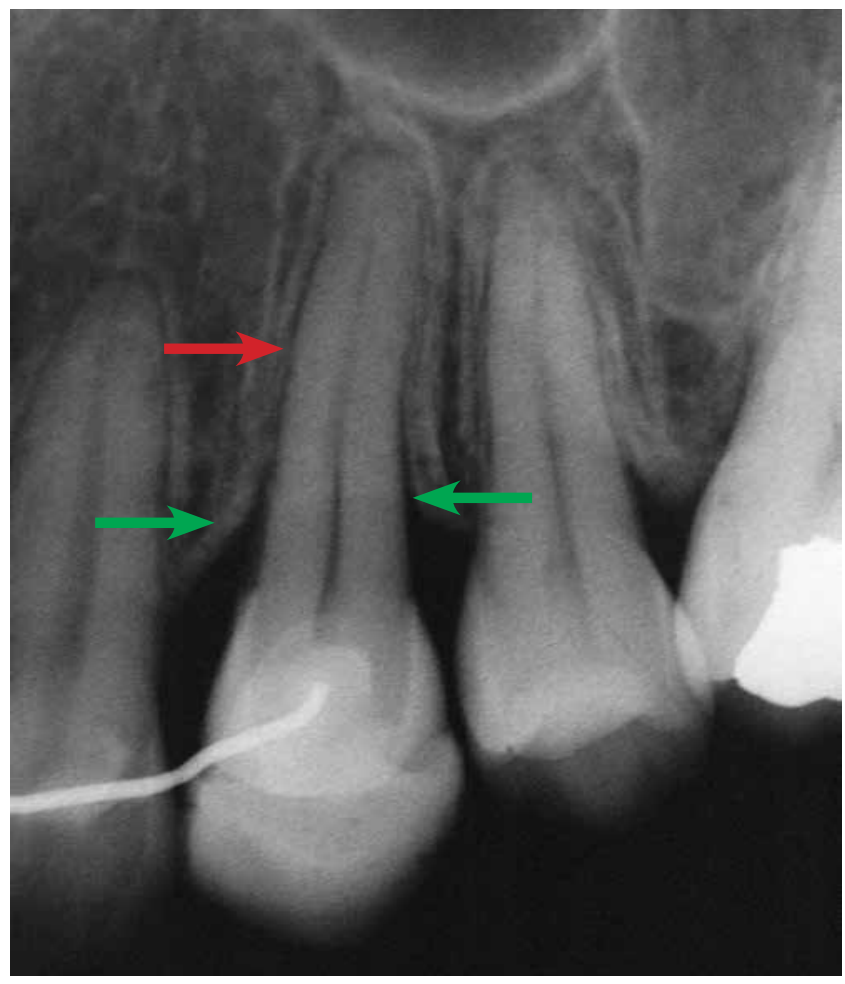

Figure 4 - Occlusal Trauma with thickening of the lamina dura, widening of the periodontal space and increased diffuse periodontal bone density (red arrow), with vertical bone loss (green arrows). with surgical procedures - with results being analyzed microscopically at a later date - is the positioning of fibroblasts and collagen fibers parallel to the root surface after scraping and treatment, without reattachment of perpendicular and functional periodontal fibers. This occurs simultaneously and alternately in gum and bone grafting.

The extremely satisfactory outcomes achieved by these surgical procedures using gingival grafts stem from the formation of a long junctional epithelium and the maintenance of post-operative gingival levels indefinitely. Epithelial cells can colonize these tooth surfaces previously exposed in the mouth and contaminated by LPS, after the surfaces have been scraped and treated.

Unfortunately, some consistent evidence to confirm these clinically obtained results are still lacking, mainly due to methodological difficulties in clinical and experimental work. As for the reattachment of fibers to surfaces previously exposed for long periods in the mouth, under the agency of bacterial plaque, no sound, methodological evidence is available as yet.

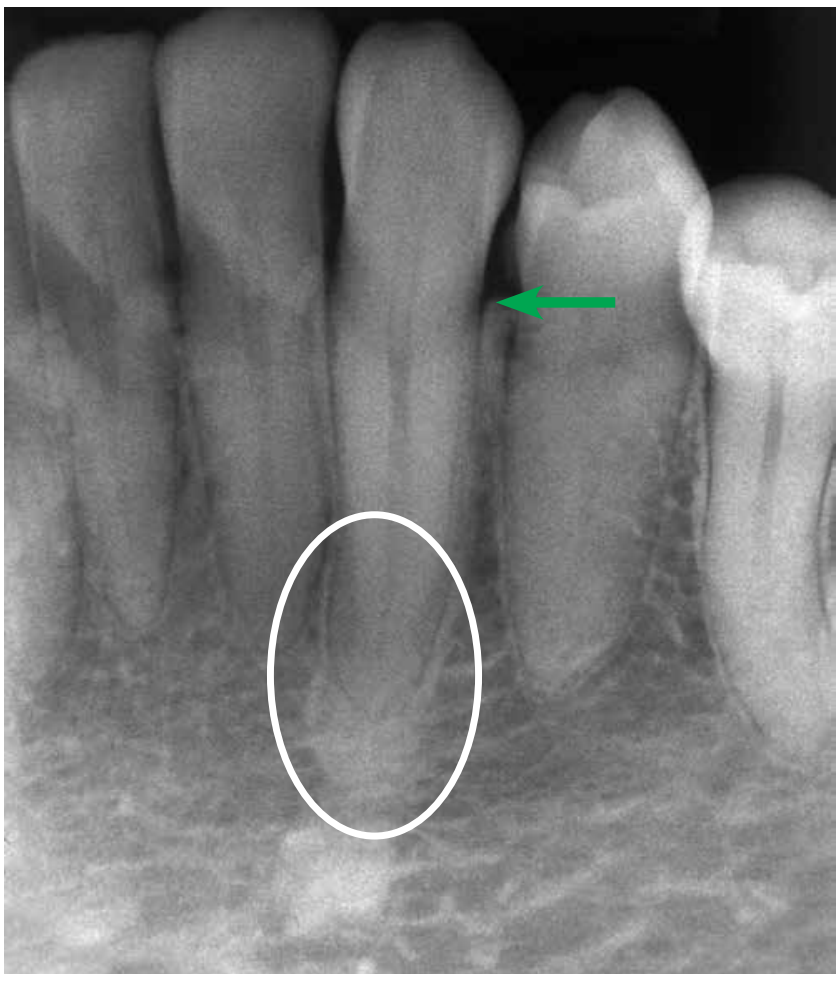

Figure 5 - Note occlusal trauma with considerable increase in periapical bone density (circle) and in the bone crest (green arrow). 


\section{CONCLUSIONS}

The mechanisms involved in the tissue changes that characterize injuries induced by occlusal trauma should not be likened to injuries caused by orthodontic movement. Although both events result from forces, the forces have completely different characteristics in terms of intensity, duration, frequency and form of periodontal tissue uptake.

In cases of V-shaped recession, one should try to carefully identify the existence of occlusal interference or overloads and correct them if possible with the aid of an occlusion specialist. At the same time, one should investigate the presence of wear facets by friction, and abfraction, to compose the triad that defines the clinical diagnosis of occlusal trauma.

It is only in periapical films, and not in panoramic $\mathrm{x}$-ray, that V-shaped vertical cervical bone loss, thickening of the lamina dura, irregular widening of periodontal space, and increases in density or apical bone sclerosis, or in the bone crest can indicate the presence of occlusal trauma. These images appear only in more advanced, long-lasting cases. Much later, there may be areas of inflammatory root resorption, but only a few months or years after the onset of the occlusal trauma.

After correcting the occlusion, one should eliminate or mitigate the damage inflicted: Smoothing of surfaces with wear facets, correcting and restoring the abfraction and, when $\mathrm{V}$-shaped gingival recession is too severe, using gum grafts. In some cases, gingival recession remits without surgery after removal of the occlusal trauma by a specialist.

\section{REFERENCES}

1. Consolaro A. Reabsorções dentárias nas especialidades clínicas. 3ae ed. Maringá: Dental Press; 2012.

2. Consolaro A. Abrasão dentária: importância do seu diagnóstico diferencial com outras lesões cervicais. Rev Dental Press Estét. 2007;4(2):124-32.

3. Consolaro A. Trauma oclusal antes, durante e depois do tratamento ortodôntico: aspectos morfológicos de sua manifestação. Rev Dental Press Ortod Ortop Facial. 2008;13(6):21-4

4. Consolaro A, Consolaro MFMO. Abfração: hipersensibilidade, trauma oclusal e outras lesões cervicais não cariosas. Rev Dental Press Estét. 2006:3(3):122-31.

5. Consolaro A, Consolaro MFMO, Francischone L. Atrição e suas implicações clínicas. Rev Dental Press Estét. 2007;4(1):124-32.

6. Consolaro A, Francischone L, Consolaro MFMO. Atrição dentária: implicações ortodônticas. Quem envelhece mais o arco dentário: o apinhamento ou a atrição? Rev Clín Ortod Dental Press. 2008;7(6):102-9.
7. Consolaro A, Consolaro MFMO. Abfração dentária no diagnóstico e planejamento ortodôntico. O que significa? Rev Clín Ortod Dental Press. 2009;8(1):104-9.

8. Lindhe J, Karring T, Lang NP. Tratado de periodontia clínica e implantologia oral. 3 a ed. Rio de Janeiro: Guanabara Koogan; 1999.

9. Solnit A, Curnutte D. Occlusal correction: principles and practice. Chicago: Quintessence; 1988

10. Stillman PR. The management of pyorrhea. Dent Cosmos. 1917;59:405-14.

11. Thiago A, Araújo MG. Trauma oclusal causa recessão gengival? Rev Dental Press Periodontia Implantol. 2009;3(1):30-2. 